\title{
On the Weariness of Time: El Niño in the Philippines
}

\author{
Christian Jil Benitez
}

https://orcid.org/0000-0002-0654-1698

Ateneo de Manila University, The Philippines

\begin{abstract}
As a rehearsal of a "tropical imaginary" that attempts to accentuate the entanglement of literature with the material world, this essay 'coincides' Jose F. Lacaba's 1965 poem "Ang Kapaguran ng Panahon" ("The Weariness of Time") with the 2015 El Niño phenomenon in the Philippines and its violent culmination the following year in Kidapawan City, Cotabato Province, Mindanao. While time or panahon in the Philippine tropics is usually intuited as generative, this essay outlines the possibility of its being worn down, not simply as a "natural" consequence of the present climate emergency, but as a critical outcome of the predominant political infrastructures that practically prohibit the phenomenon of time from unfolding. As such, it becomes imperative to recognize that beyond the current conditions banally imposed as "arog talaga kayan" or "how things really are" is the urgent need for social reform-daring tropical imaginings through which Philippine time can possibly become anew.
\end{abstract}

Keywords: panahon, Philippine time, drought, slow violence, climate emergency, El Niño, tropical imaginary

eTropic: electronic journal of studies in the tropics publishes new research from arts, humanities, social sciences and allied fields on the variety and interrelatedness of nature, culture, and society in the tropics. Published by James Cook University, a leading research institution on critical issues facing the world's Tropics. Free open access, Scopus Listed, Scimago Q1. Indexed in: Google Scholar, DOAJ, Crossref, Ulrich's, SHERPA/RoMEO, Pandora. ISSN 1448-2940. Creative Commons CC BY 4.0 free to download, save and reproduce. To cite, include: Author(s), Title of Paper, Editors (Eds.) Special Issue Title (Special Issue) eTropic, volume, issue, year, pages and DOI: http://dx.doi.org/10.25120/etropic.20.2.2021.3819 
eTropic 20.2 (2021) Special Issue: Tropical Imaginaries and Climate Crisis

\section{ng Kapaguran ng Panahon}

Kaya't siya'y naupo sa tabi ng ilog

Sa lilim ng dahong tiklop ng akasya.

Nanlulupaypay na tumayo sa tubig

Ang patpating kangkong sa kanyang paanan.

Ang walang-agos at natutuyong ilog

Ay hindi ginulo ng mga paa niya,

At hindi kumilos ang pagod niyang bibig

Upang mapaalis ang katahimikan.

Subali't matigas ang tigang na lupa,

At hapong nagbalik siya sa kanyang silid.

Pinisil ng palad ang pikit na mata.

At siya'y huminga sa dilim, at nahiga

Nang walang-tinig sa makinis na sahig,

At tinitigan ang pundidong bumbilya. (Lacaba, 1965, p. 29) ${ }^{1}$

\section{The Weariness of Time}

So they sat by the river, beneath

The folded leaves of the acacia.

By their feet, in the water,

The thin kangkong stood droopily.

The flowless and drying river

Their feet did not disturb,

Their tired mouth did not move

To chase the quiet away.

But hard was the barren earth,

And breathless they retired to their room.

They pressed a palm to their eyes closed.

And they breathed in the dark, and laid

Without a sound on the bare floor,

Then stared at the burnt out bulb. (Translation mine) ${ }^{2}$

\footnotetext{
1 In its eventual inclusion in Jose F. Lacaba's (1996) first poetry collection, Mga Kagila-gilalas na Pakikipagsapalaran: Mga Tulang Nahalungkat sa Bukbuking Baul (Legendary Adventures: Poems Recovered from a Decaying Trunk), this poem is given a different title, "Dapithapon" ("Dusk"), while also changing the first line to "Pagod, naupo siya sa tabi ng ilog" ("Weary, he sat down by the river") (translation mine) (p. 48). This essay turns to the earlier version of Lacaba's poem given the discourse it directly initiates regarding the phenomenon of time itself, and the 50 year distance between this earlier version of the poem and the 2015 Philippine El Niño drought.

2 The Filipino third-person pronoun siya in Lacaba's original poem is singular and, crucially, gender indeterminate. Here, the pronoun is translated as they to retain the gender fluidity of the farmer portrayed. At the same time, in
} 
eTropic 20.2 (2021) Special Issue: Tropical Imaginaries and Climate Crisis

The phenomenon of the present climate emergency calls for a timely "tropical imaginary" (Lundberg, 2021) that coincides ${ }^{3}$ Jose F. Lacaba's early sonnet from 1965 with the contemporary predicament of Filipino rural farmers. ${ }^{4}$ In 2015 , fifty years after Lacaba's poem was first published, many parts of the country experienced a drought similar to the one described in the poem which affected the lives of countless farmers (Ranada, 2015). In the province of Negros Oriental, Central Visayas, as early as April of that year, the damages to the farmers' crops and livestock were already estimated to be Php 28 million ( USD 630,000) (Espina, 2015). In the provinces of Maguindanao, North Cotabato, and Sultan Kudarat, in Central Mindanao, almost all of the rice and corn crops were spoiled by the extreme heat. Altogether - along with other damaged crops such as coconut, banana, coffee, and cacao - 11,292 farmers were projected to have incurred a loss of Php 103.7 million ( USD 232,000) by May of that scorching year (Ranada, 2015).

Although such "weariness of time"-or what Lacaba metonymically describes as the "barren earth" and "drying river"-as experienced in 2015 was a distinctly severe instance of the El Niño phenomenon (de la Cruz, 2014), the occurrence of drought was not entirely new and does not remain foreign for many Filipino farmers today. In reality, most farmers have learned over time to adapt to similar extreme circumstances. For instance, in the town of Libmanan in Camarines Sur in the region of Bicol, farmers, prompted by their avowed "automatic" readiness for droughts, would temporarily move to the nearby town of Paracale and shift trades to work as gold miners (Manalo et al., 2020, p. 6). Meanwhile, in the town of Anao, in Tarlac, Central Luzon, the farmers who regard agricultural labour as a crucial part of their identities adopt a different strategy, resolving to stay in their hometown and resorting instead to borrowing money or selling their remaining livestock merely to have sufficient capital for the next sowing season (Manalo et al., 2020, pp. 8-9). With such tactical acclimations - their varied exhibitions of individual mêtis or the "idiom of quick change" (Flores, 2014, 61) which grants them imaginative resourcefulness-these farmers

doing so, the singularity of siya is also displaced by the often connoted plurality of they, rendering the translation here to be a reimagining of Lacaba's poem, in which the solitary instance is transposed to a collective experience. 3 Coincide operates here as an action that the essay performs, that is to say, the essay coincides two "events," namely a 1965 poem and 2015 drought. I hope to propose this gesture of "coincidental" reading as a counter/reaction to the discipline of "comparative" reading whose juxtapositions are often hinged primarily on spatial differences, in contrast to the present attention to the temporal.

${ }^{4}$ While Lundberg (2021) articulates the tropical imaginary in relation to climate change through creative production, particularly in the works of the Indonesian artist Slinat, I rehearse here the same "material poetics" (p. 98 ; see also Lundberg, 2008) through a materialist reading —a belabouring that is as much a creative production-that coincides Lacaba's poem with what initially appears to be an historically distinct, if not completely separate, event, namely the Philippine drought of 2015. In doing so, a certain predicament on time is intimated - what Nixon (2011) calls an "attritional catastrophe," or that which "overspill[s] clear boundaries in time and space...that simplif[ies] violence and underestimate[s]...the human and environmental costs...smooth[ing] the way for amnesia..." (p.7). In this rehearsal of tropical imagining, I propose as well a reversal of the rhetoric flow described by Lundberg (2021), through bringing the discourse on climate change this time from "the specific, artistic and local," as concretized by Lacaba's poem, and back to the "general, scientific and global," as embodied in the juxtaposed Philippine historical moment (p.98). 
eTropic 20.2 (2021) Special Issue: Tropical Imaginaries and Climate Crisis

ultimately embody the Philippine notion of time in its etymological sense: panahon, from the obscure root nahon, which denotes adaptive labouring that entails a conscious turn to the most timely approach, including the possible movement to an entirely different place (Benitez, 2019b, pp. 468-471). ${ }^{5}$

Bearing in mind the Filipino farmers' capability to adapt their way through droughts, the last stanza in Lacaba's poem can now be read in a different light. The retiring of the farmer to their room, their laying "without a sound on the bare floor", their "star[ing] at the burnt out bulb", can be intuited as not merely an instance of thoughtless gazing - that idiomatic helpless perishing into an impending famine ${ }^{6}$ - but as perhaps a contemplative moment on what they could do to keep up with the apparent "weariness of time." Therefore, while by the end of the poem the farmer could be perceived as despairing, they can also be recognized as still insisting on their agency: as the river runs dry and the earth becomes barren, the farmer still possibly dares to imagine the prospects of adapting, if not outright flourishing, amid the present crisis albeit in ways that may differ from what they were formerly accustomed to. After all, such keeping pace with Philippine time is an imperative in the tropical archipelago, or as a farmer from Libmanan - evoking the perpetual likelihood of the weather and seasons at large to change drastically at any moment - puts it, "Mayong maginibo, arog talaga kayan" (Manalo et al., 2020, p. 8): "there's nothing that can be done, that's how it really is" (translation mine). And so, in the end, it appears that the farmers can only depend upon their own mêtis: as another farmer from Anao contemplates, the condition of the atmosphere might change "[in] just a wink of an eye," but their family "will not be poor as long as [he is] healthy" (Manalo et al., 2020, p. 8), that is, as long as he will be able to adapt to the changes unfolding over time. ${ }^{7}$

In this sense, despite the perceived weariness of the farmer in Lacaba's poem, they are also figured to be incessantly at labour. For even when they appear to be at restthat is, when they seem to have completely lost all hope, lying wordlessly on the bare floor, staring at the burnt out bulb-they are still actually at work, in their unrelenting imaginings of ways to confront the vicissitudes of time in the tropics. In other words, even before the farmer in the poem moves to another place to work in a different trade,

\footnotetext{
${ }^{5}$ Here, it is interesting to note Flores's (2014) description of the "polytropic Philippine," whose mêtis demonstrates the multiplicity encouraged by the Philippine temporality: "the polytropic Philippine is temporary, alien or exile, guest worker or second family, surrogate mother or housekeeper, first teacher or mail order bride, plural in its sympathies, assuming the grief of others and suffering its own, moving-mobile and heart wrenching, modern and melodramatic_-and compassionate in many ways, that is, suffering together with passion" (p.61).

6 In Filipino, the idiom "ang mamatay nang dilat," "to die with eyes open," pertains to dying caused by extreme hunger. For instance, Calvento (2017) uses this idiom as the headline of their report on the aftermath of 6.7 magnitude earthquake in Surigao City, Surigao del Norte, Northeastern Mindanao, back in 2017, with a similar inadequate response from the government.

7 This rather understated discourse between one's health and their capacity to keep pace with time is also articulated in the Philippine notion of panahon, through the common understanding of the term as the particular moment in which a given material is at its most bountiful (see Benitez, 2019b, p.464).
} 
eTropic 20.2 (2021) Special Issue: Tropical Imaginaries and Climate Crisis

or rehearses other acclimating tactics in order to overcome the crisis at hand, their toiling has already been happening the moment they start imagining what such performance could be. Here, it can then be deduced that the "weariness of time" that Lacaba portrays and argues for in his sonnet is not only the ecological wornness concretized by the drought, or the tiredness that the farmer experiences after an entire day of fruitless work on the barren fields. Instead, this weariness is also the exhaustion suffered by the farmer from their unceasing psychological and emotional labour that is anticipated to be embodied likewise by their arms and legs in due time. ${ }^{8}$ In this way, it is also the weariness that seems to prohibit itself from appearing as such, and instead manifests as merely the "natural" instinct to adapt to the times, given the way things "really are."

In other words, that labour must be rehearsed even during the purported moments of rest appears to be a demand of nature itself, for such is a suffering imagined to be in accordance to "how nature really is." After all, things-among them the bodies of water and land-are not always bountifully generous to humans in the easiest of ways, and so keeping pace with these things and the capricious changes of time itself is merely crucial for human survival. In Philippine terms especially, a time or panahon given for and named after a particular thing, say a species of flora, only signals the delimited duration of its plenitude: to say "panahon ng mangga" or the "time of mangoes" is to also point out the rest of the year in which these yellow fruits are nowhere to be found (Benitez, 2019b, p.464). One might insist their way toward the sweetness of mangoes through synthetic means such as using calburo or calcium carbide, but the resulting ripeness can only taste insincere: "hinog sa pilit", "ripened out of force."9

And yet, at the same time, the supposition of nature existing "how it really is" allows the intuition that even its most tropical swerves can be studied. Historically, the repetitive phenomena of things-indeed, their most perceptible, and thus learnable, rhythms-have granted humankind the capacity to somehow anticipate prospective futures, through timing with such cadences (see Rifkin, 1987). For instance, in 2013, scientists suggested another, and purportedly "improved", way of detecting eventual droughts through network science (Ludescher et al., 2013); such a proposition, of course, is a mere addition to a number of already preexisting forecasting procedures. In the case of the Philippine drought of 2015, its severity was already foreseen a year

\footnotetext{
8 Indeed, as Marx (1990) succinctly reminds us, the farmer's "working day contains the full 24 hours, with... rest without which labour-power is absolutely incapable of renewing its services. Hence, it is self-evident that the worker [in this case, the farmer] is... labour-power for the duration of his whole life..." (p. 375).

${ }_{9}$ It is interesting to note here an ordinance proposed back in 2015 that prohibits the use of calburo to induce ripening to fruits (see Councilor: Don't use 'calburo' to ripen fruits, 2015): given the present preoccupation of the essay on the temporal, such ordinance can now be understood as primarily concerned-albeit, of course, unconsciously_on time, with its aspiration perhaps to resist the pressure from both the local and global markets to make these fruits perpetually available products, oftentimes to the detriment of "a balanced ecology," among others, that is protected by the provisions of the Philippine Republic Act of 7160.
} 
eTropic 20.2 (2021) Special Issue: Tropical Imaginaries and Climate Crisis

prior its occurrence, and so as early as 2014 a national preparation was already asserted (Alampay \& dela Torre, 2020). In May 2014, the Philippine Department of Agriculture commenced cloud seeding operations over Mindanao to facilitate the formation of more rain clouds over the area. At the same time, the Department also distributed seeds of a rice variant called "Rio Grande," valued for its quicker growth and more abundant yield compared to common variants, despite the likelihood of depleted watering (Ranada, 2014).

However, as demonstrated by the damages suffered by many Filipino farmers from that same El Niño drought, these government-initiated preparatory efforts did not equate to the successful adaptation of the country at large to the vicissitudes of time and the turns of the tropical climate. And although the local farmers then-and by extension, imaginably, the farmer in the milieu of Lacaba's poem-could have attempted to further insist upon their needs amid such ecological crisis, their struggles would not have necessarily elicited an immediate (or even any) response from the government. For instance, as the fatal drought of 2015 continued into the following year, by the end of March 2016 over 500 farmers from North Cotabato gathered in front of the National Food Authority office in Kidapawan City to voice out their urgent concerns. Despite North Cotabato having been officially declared under a state of calamity, around 15,000 sacks of rice previously promised by the local government remained undistributed among the affected families. The following day, over 6,000 people joined the gathering to express their solidarity. The sheer numbers made the participants spill over the Cotabato-Davao Road, inevitably causing a massive traffic jam in the city. Local police attempted to reach a compromise with the farmers and their supporters in order to ease the traffic; however, on the following day the negotiations culminated in violence. On April 1, 2016, over 150 people - protestors and police - were injured, and three among the protesters were killed (Macas, 2016).

With the Philippine national government claiming that the drought had little effect on the country, despite its severity on the lives of many citizens (Department of Agriculture, 2016; Pastor, 2016), it becomes understandable that for many Filipino farmers the damages due to drought and the necessity of individual acclimating tactics are simply construed to be how things "really are". In the midst of similar violent responses-including the lack of response itself-from the government, the farmers are ultimately "shown that it is not for the farmer to protest and criticize [the government], and they must simply remain quiet in the midst of poverty...that it is not natural for the farmers from the countryside to protest..." ("ipinapakita.. sa kanila na hindi dapat maging gawain ng magsasaka ang magprotesta at magreklamo, at dapat na manatiling tahimik lamang sila sa gitna ng kahirapan... na hindi natural sa mga magsasaka sa kanayunan ang magprotesta...") (Gealogo, 2019). In effect, the phenomenon of suffering-including the daily weariness these famers endure-is not 
eTropic 20.2 (2021) Special Issue: Tropical Imaginaries and Climate Crisis

only banalized (see Arendt, 1963), but also naturalized, in its particular framing as an inevitable consequence of being materially entangled with the natural world.

And yet, any instance of incisive historicization intimates how the "natural" is always a composition in time: what might first appear as native and inherent is only insofar as its prior emigration or transplantation has been effectually forgotten, discursively concealed by its eventually acquired ordinariness, if not organicity. ${ }^{10}$ Such are the workings of a catastrophe that is "slow and long lasting," one that unfolds across "unspectacular time," and is especially nourished by "vast structures that...constitute forms of violence in and of themselves" (Nixon, 2011, pp. 6, 10). This catastrophe includes the perpetuation of notions of the "natural" that primarily desire to preserve certain worldly configurations beneficial to only a few. This is the very irony perceived in the midst of the present Philippine climate emergency: that despite the collective experience of extreme changes brought by droughts and other phenomena induced by climate change, a certain stubbornness swarms and infests political structures, one that strategically denies the precarious situation of their constituents, and instead insists on things to keep going as they purportedly "really are." Farmers are commanded to continue their labour under the harsh tropical heat, no matter how fruitless such pursuits are in a time of drought; any attempt to implicate those who wield greater socio-political power within such crisis will only be reciprocated with bullets, instead of much needed rice grains. ${ }^{11}$

This then must be what Lacaba intuits as "the weariness of time" itself: a wornness that is not necessarily the exhaustion of time, with its promise of possibilities in the face of such severe phenomenon as drought; but the attrition of things in their having been prohibited the opportunity to turn and emerge alternatively. In other words, it is the institutional forbidding of time itself from practically taking place: not merely the mechanization of time in having a singular clock time across the Philippine tropics, flattening its otherwise plural temporalities for the sake of "the adamant dream toward a nation-state" (Benitez, 2021, p.42; see also Benitez, 2019b, p.458), but also the

\footnotetext{
10 The Philippine term likas is particularly instructive here. Stressing the word's second syllable (likás) renders it to denote the "natural"; while shifting the emphasis to its first syllable ((likas) renders it as "unnative," as in what could have been previously transplanted or emigrated. It is crucial to underscore that what ultimately demarcates these definitions is time itself: aside from the fact that it is an instant of a speech act that determines where the word will be accented, duration itself in the world at large also permits the practical assimilation of something into a given material ecology, which could eventually grant a transplanted thing its belongingness. In this way, it can ultimately be imagined that "an emigrant (líkas) can only be the eventual native (likás)" ("líkas din lamang sa isang banda ang kinalaunang likás") (Benitez, 2019a, p.v).

11 This was sharply articulated by the social media hashtag that emerged as a response to events in Kidapawan City: \#BigasHindiBala, literally "Rice grains, not bullets," pertaining to the violent response to the gathering, rather than listening to and providing for the needs of the affected farmers (see Tupaz, 2016). It is also crucial to note here that this aphoristic line reemerged four years later, amid the 2020 COVID-19 pandemic: \#BigasHindiDahas, "Rice grains, not violence," pertaining to the brutal police response to 21 residents of Sitio San Roque, Quezon City, Metro Manila, who gathered-while being mindful of the necessary health protocols of the time-to call the attention of the local government to the promised aid still unreceived in the early months of the long Philippine lockdown (See Tandog, 2020; and Sitio San Roque: Bigas hindi dahas, 2020).
} 
eTropic 20.2 (2021) Special Issue: Tropical Imaginaries and Climate Crisis

discursive impeding of its history, its barring from being imagined, and thus unfolded - differently. It is the seemingly natural circularity of Philippine time which is, in reality, constructed, imposed, and self-replicated over and over again through the coordination of various political infrastructures. ${ }^{12}$ It is the questionable "universality" of Lacaba's poem from 1965, its problematic "verisimilitude" 50 years later in 2015, which is grounded in the simple fact that to this day farmers still need to tactically acclimate to droughts and other climatic extremes on their own. Farmers are still ultimately deprived of sufficient relief and structural support from the government, and instead coerced to perceive that their suffering will always be "how it really is," leaving them to their own devices.

The "weariness of time," in other words, is also a consequence of its prohibition, its being held captive to "a bad repetition, a vicious circle, a regressive or sterile process" (Derrida, 1992, p.9) wherein time itself has become something to which "mayong maginibo"- "there's nothing to be done." Therefore, the "weariness of time" is also the failure of imagining possibilities of time; or of merely imagining time as irrefutably and irreversibly attrit, when in reality, its any given instance can always be desired to turn into another (Benitez, 2019b, p.465), not only through the sheer mêtis of individuals but also through structural political gestures in general.

The necessity of imagining time alternatively returns us to Lacaba's poem, calling for a rereading of its final line in hopes of reconfiguring the farmer's staring at the burnt out bulb as a possible moment for emergence. Here, one can imagine that perhaps, in such an instance, not only does the farmer think of what tactics they could undertake to keep time with the drought they currently suffer, but they may also begin to interrogate the phenomenon of time itself, studying its long-enduring idiom of "how things really are" - if only to decompose and unlearn it. That, maybe, in their own language-most likely more lucid and urgent, distilled from poetry, far different from what I rehearse in this brief prose already alienated even to myself as an academic who coincides all these things at a glance, creating a "single spectacle from a point of privileged invisibility" (McClintock, 1995, 37) ${ }^{13}$-this is the initial moment of imagining, no matter how fleeting, of how things can also be not how they purportedly "are." In such a moment of patient looking, an epiphany may arrive-and indeed is hoped to arrive - to the farmer laying soundlessly on the bare floor, breathing in the dark: that there still lingers the plenitude of things, whose potential only remains dormant due to the deterrence of the powerful few; and that there is an inevitable interconnectedness

\footnotetext{
12 This perceptible circularity of Philippine time can be instantiated in the present experience of COVID-19 pandemic in the archipelago, and under the Rodrigo Duterte regime, with its particular promise that "change is coming," yet ultimately regressing to the same structural violences comparable to those afflicted decades ago during the dictatorship of Ferdinand Marcos (see Benitez, 2020).

${ }^{13}$ McClintock (1995) particularly relates this privilege to "the image of global history consumed—at a glance," that which she calls "panoptical time" (p.37).
} 
eTropic 20.2 (2021) Special Issue: Tropical Imaginaries and Climate Crisis

in all these things, "natural" and not, the farmer themself included, the reflexive recognition of which can allow the critical to unfold.

\section{from Pag-aaral sa Oras}

Pinag-aaralan ko

Ang paghihimbing at pagkurap.

Ang una'y pangangarap,

Ikalawa'y pagsipi ng tanawin

Mula sa isang sulyap.

Ano ang pagsipat?

Ito'y walang iba kundi

Komprehensibong pagsisiyasat.

Kung gayon, ano naman

Ang kisapmata at pagmumulat?

Ang mga ito ay usapin ng oras

Na sinasayang o iniipon,

At ng mga pagkakataong

Sinusunggaban o tinatapon.

Ang lahat ng ipinundar

Sa paraan ng pagmumulat

Ay huwag ibasura

'Wag ihagis sa pusali

Sa isang kisapmata

O 'sangsikap pa at kalahati! (Tariman, 2017, p. 124)

\section{from Study on Time}

I study what it is

To sleep and to blink.

The first is to dream,

The second is to extract the view

From a single glance.

What is to look?

This is nothing but

Comprehensive inspection.

And so, what then

Is a blink of an eye, its opening?

These are matters of time

Wasted or gathered

The timings 
eTropic 20.2 (2021) Special Issue: Tropical Imaginaries and Climate Crisis

\author{
Taken or thrown. \\ Everything earned \\ Through opening the eyes \\ Must not be thrown \\ Don't throw it to the mire \\ In a blink of an eye \\ Or an effort and a half! (translation mine)
}

Perhaps, in such a crucial moment of looking —and maybe, only in such a momentcan time itself become anew. ${ }^{14}$

\footnotetext{
${ }^{14}$ I use anew here as a modifier to the verb become, as in the Deleuzean sense of "becoming" (see Bankston, 2017). In other words, time "becoming anew" points to the moment of its unfolding once again; its turning into another. But while "becoming anew" can be rearticulated indeed as such "unfolding," "turning," or other similar action words that might be even deemed as "more direct," or at least "palatable," the term "becoming anew" is insisted here, considering how during the process of copyediting this essay, the said phrase initiated an entire event of unpacking that somehow performs what I mean by "time becoming": the re/consideration of the phrase back and forth between myself and the editor, in our respective locations in the Philippines, Indonesia, and Australia, allowed time itself to happen, and emerge generatively. It seemed that the more we tried to talk about this particular phrase, the more time it opened for us, and this way, the more ironic our very exchange has become for me: somehow, we were within the phrase; we have become what we were trying to understand. Such can only be an instance of coincidental reading.
} 
eTropic 20.2 (2021) Special Issue: Tropical Imaginaries and Climate Crisis

\section{References}

Alampay, E.A., \& dela Torre, D. (2020). Addressing Slow Onset Disasters: Lessons from the 2015-2016 El Niño in the Philippines. In W.L. Filho (Ed.), Handbook of Climate Change Resilience (Vol. 3, pp. 2125-2142). Springer.

Bankston, S. (2017). Deleuze and Becoming. Bloomsbury Publishing.

Benitez, C.J.R. (2019a). Pagsasalin, Bilang Kumpas Ekokritiko. Katipunan, 4, v-viii.

Benitez, C.J.R. (2019b). Panahon and Bagay: Metonymy and the Close Reading of

Dictionaries to Understand Filipino Temporality. Philippine Studies, 67(3-4): 457-488. https://doi.org/10.1353/phs.2019.0023

Benitez, C.J.R. (2020). \#DuterteStandardTime: Pamamahalang Pamanahon. Katipunan, 6, 60-81.

Benitez, C. J. (2021). No Wild Iris. In Lundberg, A., Ngalamulume, K., Segata, J., Termizi, A.A., \& Spicer, C.J. Pandemic, Plague, Pestilence and the Tropics [Special Issue]. eTropic: Electronic Journal of Studies in the Tropics, 20(1), 42-53. https://doi.org/10.25120/etropic.20.1.2021.3773

Calvento, A. (2017, February 17). 'Dilat ang mata na mamatay.' PhilStar. https://www.philstar.com/pilipino-star-ngayon/opinyon/2017/02/17/1672526/dilat-angmata-na-mamatay

Councilor: Don't use 'calburo' to ripen fruits. (2015, March 2). SunStar Philippines. https://www.sunstar.com.ph/article/396188/Business/Councilor-Dont-use-calburo-toripen-fruits-

de la Cruz, G. (2014, November 8). How El Niño could affect in the Philippines in 2015. Rappler. https://r3.rappler.com/science-nature/environment/73542-prepare-droughtless-rainfall-2015

Department of Agriculture. (2016, March 9). Cloud seeding aids in mitigating the impact of El Niño. Official Gazzette. https://www.officialgazette.gov.ph/2016/03/09/cloud-seedingmitigating-impact-el-nino/

Derrida, J. (1992). Given Time: 1. Counterfeit Money (P. Kamuf, Trans.). University of Chicago Press.

Espina, M.P. (2015, April 17). Negros Occidental incurs P28M agri losses due to dry spell. Rappler. https://www.rappler.com/business/negros-occidental-agriculture-lossesdrought

Flores, P. (2014). Philippine Polytropic: Intimating the World in Pieces. In Antoinette M. \& Turner C. (Eds.), Contemporary Asian Art and Exhibitions: Connectivities and Worldmaking (pp. 47-66). ANU Press.

Gealogo, F. (2019, September 24). Krisis sa bigas o paano mag-alay ng tula sa mga magsasaka. Bulatlat. https://www.bulatlat.com/2019/09/24/krisis-sa-bigas-o-paanomag-alay-ng-tula-sa-mga-magsasaka/

Lacaba, J.F. (1965). Ang Kapaguran ng Panahon. Heights, 14(1), 29.

Lacaba, J.F. (1996). Mga Kagila-gilalas na Pakikipagsapalaran: Mga Tulang Nahalungkat sa Bukbuking Baul ( $2^{\text {nd }}$ ed.). Office of Research and Publications, Ateneo de Manila University.

Ludescher, J., Gozolchiani, A., Bogachev, M.I., Bunde, A., Havlin, S., \& Schellnhuber, H.J. (2020). Improved El Niño forecasting by cooperativity detection. Proceedings of the National Academy of Sciences 110(29), 11742-11745. https://doi.org/10.1073/pnas.1309353110

Lundberg, A. (2008). Material poetics of a Malay house. The Australian Journal of Anthropology, 19(1), 1-16. https://doi.org/10.1111/i.1835-9310.2008.tb00102.x 
eTropic 20.2 (2021) Special Issue: Tropical Imaginaries and Climate Crisis

Lundberg, A. (2021). Balinese dancer wearing a gas mask: climate change and the tropical imaginary. Scottish Geographical Journal, 136(1-4), 91-100. https://doi.org/10.1080/14702541.2020.1858589

Macas, T. (2016, April 4). How the protest of hungry farmers turned into a deadly dispersal in Kidapawan. GMA News Online. https://www.gmanetwork.com/news/news/regions/561478/how-the-protest-of-hungryfarmers-turned-into-a-deadly-dispersal-in-kidapawan/story/

Manalo IV, J.A., van de Fliert, E., \& Fielding, K. (2020). Rice farmers adapting to drought in the Philippines. International Journal of Agricultural Sustainability, 1-12. https://doi.org/10.1080/14735903.2020.1807301

Marx, K. (1990). Capital: A Critique of Political Economy (Vol. 1; B. Fowkes, Trans.). Penguin Classics. (First published 1976)

McClintock, A. (1995). Imperial Leather: Race, Gender and Sexuality in the Colonial Contest. Routledge.

Nixon, R. (2011). Slow Violence and the Environmentalism of the Poor. Harvard University Press.

Pastor, R. (2016, April 5). Kidapawan and why the Philippines is always short of rice. Rappler. https://r3.rappler.com/thought-leaders/128233-kidapawan-why-philippinesshort-of-rice

Ranada, P. (2014, May 8). Gov't prepares PH agriculture sector for El Niño. Rappler. https://www.rappler.com/nation/philippine-agriculture-preparing-el-nino

Ranada, P. (2016, May 6). 100\% crop damage reported in parts of Mindanao due to drought. Rappler. https://www.rappler.com/nation/mindanao-crop-failure-drought-oxfam

Ranada, P. (2015, June 5). DA awaits P939 million budget for El Niño efforts. Rappler. https://www.rappler.com/nation/department-agriculture-el-nino-budget

Rifkin, J. (1987). Time Wars: The Primary Conflict in Human History. Henry Holt.

Sitio San Roque: Bigas hindi dahas. (2020, April 3). Kadao. https://kodao.org/sitio-sanroque-bigas-hindi-dahas/

Tandog, T.K.C. (2020, April 30). 'Bigas Hindi Dahas': Covid-19 and state violence. Fieldsights. https://culanth.org/fieldsights/bigas-hindi-dahas-covid-19-and-stateviolence

Tariman, K.L. (2017). Pag-aaral sa Oras: Mga Lumang Tula Tungkol sa Bago. High Chair.

Tupaz, V. (2016, April 3). \#BigasHindiBala: Online support for Kidapawan drought protest grows. Rappler. https://r3.rappler.com/move-ph/128081-bigashindibala-onlinesupport-drought-protest-kidapawan

Christian Jil Benitez teaches Filipino at Ateneo de Manila University where he earned an AB-MA in Filipino literature (2016/2018). Hailed as Poet of the Year 2018 by the Commission on the Filipino Language, his critical and creative works on time, tropicality, and materiality have appeared in Katipunan, Kritika Kultura, Philippine Studies, Res Rhetorica and eTropic journal, among others. He lives in Rizal, Philippines. 